\section{E-LOGOS}

ELECTRONIC JOURNAL FOR PHILOSOPHY ISSN 1211-0442

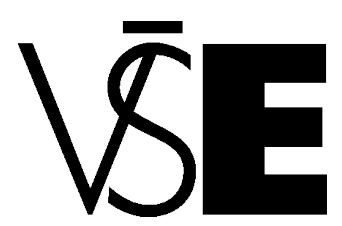

University of Economics

Prague

\title{
Homo economicus - překonaný předpoklad?
}

\author{
Jitka Melzochová
}

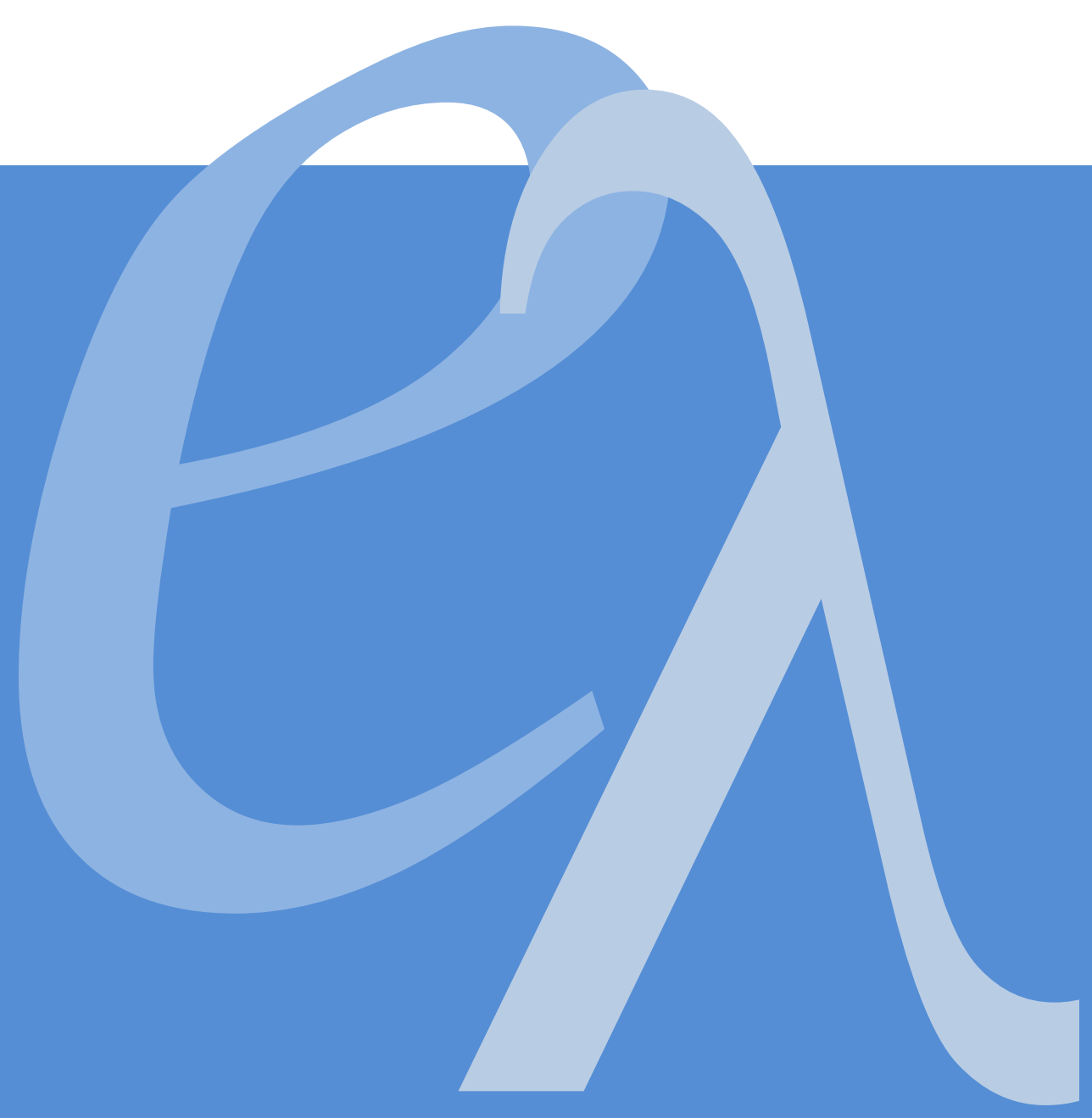




\begin{abstract}
The neoclassical approximation of human behavior is contained in the assumptions of model of homo economicus. Work corresponds negatively to the question whether the neoclassical concept is obsolete. Criterion for overcome model it considers poor predictive ability of the model and its replacement by an alternative concept. The work is focused only on the adjustment of assumptions of the model involves shifting acting agent closer to reality and it does not deal with the rejection of the model based only on the evidence of real action that does not match the assumptions of the model. It deals with the theory of bounded rationality, the results of behavioral experiments and Becker extended utility function. The following it explains why subjects with ineffective behaviors survive in the market, and because of the lack of evolutionary pressure. I conclude that the model of homo economicus is not an outdated model, since it allows enlargement, leading to higher-quality predictions of human behavior.
\end{abstract}

Keywords: homo economicus, rationality, bounded rationality, behavioral economics, cultural evolution

\begin{abstract}
Abstrakt
Neoklasická aproximace lidského jednání je obsahem předpokladů modelu homo economicus. Práce odpovídá negativně na otázku, zda je neoklasický koncept překonaný. Za kritérium pro překonanost je pokládána nekvalitní predikční schopnost modelu a jeho nahrazení alternativním konceptem. Práce je zaměřena pouze na úpravu předpokladů modelu člověka ekonomického posunující jednání agenta blíže k realitě a nezaobírá se odmítnutím modelu založeným pouze na důkazech o reálném jednání, které se neshoduje s předpoklady modelu. Článek se zabývá teorií omezené racionality, výsledky behaviorálních experimentů a Beckerovou rozšířenou užitkovou funkcí. Dále je vysvětleno, proč na trhu přežívají subjekty i s neefektivními vzorci chování, a to z důvodu nedostatečného evolučního tlaku. Je dosaženo závěru, že model homo economicus není překonaným modelem, nebot' dovoluje rozšíření předpokladů vedoucí ke kvalitnějším předpovědím lidského jednání.
\end{abstract}

Klíčová slova: homo economicus, racionalita, omezená racionalita, behaviorální ekonomie, kulturní evoluce 


\section{Úvod}

Hédonistická a racionalistická aproximace lidského jednání obsažená v předpokladech neoklasického modelu homo economicus ${ }^{1}$ se stala terčem kritiky ze stran sociologů, psychologů i samotných ekonomů. Jelikož je považován model racionální volby za výchozí neoklasický předpoklad, je třeba na kritiku reagovat a argumentovat ve prospěch modelu (jsme-li zastánci neoklasické ekonomie), či v jeho neprospěch (hlásíme-li se $\mathrm{k}$ jinému ekonomickému přístupu). Předkládaná práce se drží neoklasického př́stupu a řeší otázku oprávněnosti modelu v rámci ekonomie. Cílem je zodpovědět otázku, zda je model homo economicus udržitelný, či překonaný alternativním výkladem lidského jednání a jakými argumenty lze podepř́t jeho př́padnou kritiku.

Abychom mohli nalézt odpověd' na vyřčenou otázku, je nutné nejprve jasně formulovat předpoklady neoklasického modelu. Bylo zjištěno, že zastánci neoklasické ekonomie přistupují $\mathrm{k}$ modelu jako $\mathrm{k}$ samožrejmosti, kterou netřeba zmiňovat, a proto jsou pro definici předpokladů užity práce kritiků mainstreamové ekonomie (převážně H. Simona a A. Etzioniho). ${ }^{2}$ Hlavním předpokladem modelu je rozhodující se subjekt, který je dokonale informovaný o všech možných alternativách volby, je si vědom svého omezení a vzhledem $\mathrm{k}$ omezení hledá nejlepší možnou volbu prostředků pro dosažení cílů.

V práci je kladen důraz na pozitivistickou metodologii neoklasické ekonomie, která odmítá testování předpokladů modelu pro určení kvality modelu. Již v úvodu je zdůrazněno, že tvrzení o tom, jak se lidé rozhodují (tj. samotné předpoklady modelu) nelze ověrit. Proto nelze zodpovědět otázku, zda je pravda, že člověk maximalizuje svůj užitek, že je dokonale informován atp. $Z$ tohoto důvodu se v práci nezabýváme kritikami předpokladů modelu, v nichž se tvrdí, že člověk není homo economicus. Polemika s argumentací autorů, kteří model odmítají pouze z důvodu jeho nereálných předpokladů (jako např. B. Frey, M. Sahlins, K. Polanyi a další), není cílem práce. Cílem je vymezení předpokladů modelu a posouzení, zdali existuje alternativní model lidského jednání, který by přinášel kvalitnější predikce. ${ }^{3}$ Za relevantní kritiku

\footnotetext{
${ }^{1} \mathrm{~V}$ literatuře se setkáváme i s názvem homo oeconomicus. Termín homo je latinským výrazem pro člověka. Etymologický výklad slova economicus nás odkazuje do 4. st. př. n. l., kdy Sokratův žák Xenofón napsal spis Oikonomikos pojednávající o správě majetku v patricijských domech a o roli ženy v domácnosti. Oikos - z řeč. dům, nomos - z řeč. správce, pravidlo, zákon. Homo economicus (člověk hospodařící) je tedy složeninou latinského a řeckého pojmu (stejným „"nedostatkem“ je zatížen např́ílad i pojem sociologie). Správným výrazem pro aproximaci lidského jednání z pohledu jazykové koherence je pak anthropos oikonomikos. Jelikož si neklademe za cíl měnit ekonomické názvosloví, užíváme úzus homo economicus.

${ }^{2}$ Kritiků modelu homo economicus je nespočet z různých oborů společenských věd. H. Simon a A. Etzioni byli vybráni z důvodu jejich vlastní formulace dalších motivů lidského jednání, kterými model člověka ekonomického rozšiřují.

${ }^{3}$ Je nutno dodat, že model homo economicus je často předpokladem dalších modelů vysvětlujících a predikujících lidské jednání. Text je však zaměřen pouze na predikci modelu samotného, nikoli na predikci modelů, jež jej pojímají za jeden ze svých předpokladů.
} 
předpokladi̊ modelu je proto pokládána pouze ta, která je schopna držet se rámce pozitivistické metodologie a argumenty opřít o chybnou predikční schopnost neoklasického modelu lidského jednání. Práce je zaměřena pouze na modifikaci předpokladi̊ modelu směrem $\mathrm{k}$ jejich realističnosti, čímž je dosažena lepší predikční schopnost modelu.

Jelikož je práce zaměřena pouze na možnou úpravu předpokladi̊ modelu posunující jednání agenta blíže k jednání reálné lidské bytosti, základní teorií je omezená racionalita $\mathrm{H}$. Simona postavená na uspokojivé, nikoli optimální volbě jedince. Teorie omezené racionality dala vzniknout behaviorální ekonomii, která se prostřednictvím experimentů snaží poukázat na chybné neoklasické predikce. Ačkoli se účastníci experimentů nechovají ani tak, jako kdyby byli racionální, je třeba nezapomenout, že prostředí experimentů se liší od reálného prostředí a stále udržovat stanovisko, že nelze nalézt $\mathrm{v}$ rámci pozitivismu pravdu o tom, jak a proč jednotlivci jednají. Přesto však výsledky behaviorálních pokusů, ve kterých se respondenti chovali jinak, než předpokládá neoklasická ekonomie, jsou v práci zmíněny včetně vysvětlení, proč tomu tak je.

Jak je možné, že předpoklady modelu homo economicus často neodpovídají reálnému lidskému jednání, a přesto neoklasická ekonomie poskytuje v určitých případech kvalitní predikce? Vysvětlení se opírá o teorii imitace, podle které jsou nejsilnější (efektivnější) hráči na trhu napodobováni svými konkurenty, kteří se díky nim stávají efektivnějšími a na trhu přežívají. Avšak v reálném světě lze pozorovat i dlouhodobé přetrvávání neefektivních zpơsobů jednání. Vysvětlení neefektivního stavu poskytujeme prostřednictvím zakořeněných norem jednání v rámci společnosti, jejímž je subjekt členem.

Příspěvek dochází k závěru, že neoklasický model homo economicus není překonaným předpokladem neoklasické ekonomie, i přesto, že jsou jeho předpoklady nerealistické. Je ukázáno, že neoklasický model se v historii ekonomického myšlení vyvíjel a že nepředpokládá jen sobecké hédonistické chování racionálního subjektu. Připouštíme, že při rozšiření předpokladů modelu o teorii omezené racionality, poznatků behaviorální ekonomie a rozšǐřené Beckerovy užitkové funkce model poskytuje kvalitnější předpovědi výsledků lidského jednání.

\section{Model homo economicus v neoklasické ekonomii}

\subsection{Předpoklady modelu}

Herbert Simon byl jedním z kritiků neoklasického modelu homo economicus a ve svých pracích usiloval o přeměnu předpokladů modelu směřující k reálnému chování 
lidských bytostí. ${ }^{4}$ Výsledkem jeho snahy bylo definování termínu omezená racionalita. Simon (1997, s. 291 a 1983, s. 12-13) považuje za základ modelu homo economicus teorii subjektivního očekávaného užitku (SEU teorii), která se opírá o čtyři předpoklady lidského rozhodování, a to o předpoklad:

1. správně definované užitkové funkce rozhodujícího se subjektu (kardinálně lze vyjádřit hodnotu užitku i pro budoucí situace);

2. volby z uzavřené množiny daných a známých alternativ;

3. znalosti subjektivního pravděpodobnostního rozdělení výsledku každé alternativy;

4. volby založené na maximalizaci očekávané hodnoty dané užitkové funkce. ${ }^{5}$

SEU teorie předpokládá, že „víme, co chceme“ , z čeho můžeme vybírat a zachycuje i volbu v případě nejistoty. Racionální jednání je tedy takové jednání, které se řídí maximalizací nikoli užitku, ale maximalizací očekávaného užitku.

V rámci ekonomické racionality Simon (1996) vymezil substantioní racionalitu, která se projevuje přizpůsobováním se vnějšímu prostředí (omezena je znalostmi, schopnosti) a procedurální racionalitu ústící v objevení vhodného adaptivního chování. ${ }^{6}$ Substantivní racionalitu předpokládá neoklasická ekonomie. Závisí pouze na preferencích dokonale informovaného jednotlivce, který ze souboru možných situací vybere tu, která pro něho představuje nejvyšší očekávaný užitek. Substantivní racionalita je zaměřena pouze na výsledky. Podle Simona (1996) se substantivní racionalita projevuje pouze $\mathrm{u}$ jednoduchých a dobře strukturovaných problémů. Strukturálně racionální chování lze predikovat. Je-li problém, před kterým subjekt stojí, komplexnější, spokojí se podle Simona jen s dostatečnými (nedokonalými) informacemi, situaci si sám pro sebe zjednoduší a vybere uspokojivé (nikoli jistě optimální) řešení. Procedurální (omezená) racionalita, uplatňující se u složitějších rozhodovacích problémů, nepředpokládá možnost predikce. Proces rozhodování je Simonem vysvětlen omezenou racionalitou.

Etzioni (1995) neoklasické paradigma pokládá za utilitární, racionalistické a individualistické. Jedinec racionálně volí nejlepší prostředky pro dosažení svých cílů,

\footnotetext{
${ }^{4}$ Hovoříme-li v textu o chování, máme vždy na mysli účelové chování jednotlivce.

${ }^{5}$ 2. až 4. předpoklad teorie subjektivního očekávaného užitku Simon převzal od SAVAGE, L. J. (1954). The Foundations of Statistics. New York: John Wiley.

${ }^{6}$ Simon se ve druzích racionality inspiroval u Maxe Webera (1864-1920), který popsal čtyři ideální typy racionality. Praktická racionalita se projevuje v přijmutí současné situace a ve snaze nalézt nejlepší možný způsob, jak se s danou momentální situací vyrovnat. Teoretická racionalita vede k poznání světa, realitu uchopuje pomocí abstraktních pojmů. Substantivní racionalita se projevuje ve volbě prostředků $\mathrm{k}$ požadovaným cílům. Cíle jsou přitom seřazeny podle žádoucnosti a uspokojovány jsou nejprve nejvíce žádoucí cíle. Posledním druhem racionality je formální racionalita, jež pracuje s formálními pravidly rozhodování (volba adekvátních prostředků k naplnění cílů). (Kalberg 1980)
} 
maximalizuje svou vlastní užitečnost; představuje rozhodovací jednotku. Neoklasické teorie se opírají o predikční schopnost svých modelů. Jsou-li předpovědi modelů kvalitní, nezáleží, zda předpoklady modelu jsou zjednodušené či nereálné. „Neoklasické paradigma bud' neuvažuje společenství vỉbec, nebo je bere jako agregáty jedinců bez jejich vzájemných kauzálních vztahů, které jsou vưči jednotlivým osobám vnější. Individua jsou chápána jako oddělená od společenství a od sdílených hodnot, jako kalkulující, zda být či nebýt členem, zda dbát nebo nedbat na diktát hodnot." (Etzioni 1995, s. 14) Morální dimenze lidského jednání je neoklasickou ekonomií podle Etzioniho (1995) ignorována a navíc, sami ekonomové se brání podle jeho slov jejímu začlenění do teorie. Různá uspořádání preferencí jsou brána jako daná a žádné z nich nelze považovat za lepší. Etzioniho tvrzení naráží na pozitivistický charakter metodologie neoklasické ekonomie, jež definoval M. Friedman (1997). ${ }^{7}$ Neoklasické paradigma má za základ podle Etzioniho (1995) utilitární etiku, která je hédonistická a orientovaná na já. Předpokládá existenci jednotného já, tj. člověka jako „svazek“ jednoznačných a stabilních preferencí.

Z citovaných definic modelu homo economicus předkládáme přehledné shrnutí předpokladů:

1. subjekt volí $\mathrm{z}$ uzavřené množiny daných a známých alternativ (existence př́ipustné množiny);

2. dokonale zná veškeré relevantní informace pro každou alternativu;

3. existuje pro něho jasně definovaná užitková funkce vymezující sféru jeho zájmu;

4. maximalizuje očekávaný užitek a minimalizuje náklady s ohledem na různá omezení (jako kdyby hledal vázaný extrém užitkové funkce na př́ípustné množině; jedná racionálně);

5. jeho preference jsou exogenní, stabilní, kompletní a tranzitivní;

6. volí nezávisle na pověrách, předsudcích, na minulé spotřebě, na způsobu zarámování ${ }^{8}$ problému atd.

Neoklasický model člověka ekonomického je tedy založen na metodologickém individualismu a dle Friedmanova pojetí metodologického pozitivismu je predikční schopnost modelu jediným měřítkem pro kvalitu modelu.

\footnotetext{
7 Viz následující kapitola.

8 Tzv. framing efekt (efekt zarámování) doložili Kahneman a Tversky (1981) na případu asijské nemoci. Většina respondentů (72\%) preferovala plán jistého přežití 200 lidí z 600, oproti plánu přežití 600 lidí s pravděpodobností $1 / 3$, ačkoli očekávaný počet přeživších u obou plánů je shodný. Naopak jistou smrt pro 400 lidí vybrala menšina respondentů. Majorita $(78 \%)$ zvolila plán s pravděpodobností $2 / 3$, že zemře 600 lidí.
} 


\subsection{Historie modelu homo economicus}

Schumpeter (1994) předobraz modelu nalézá u pozdních scholastiků, a to u sv. Antonína Florentského, který ve svém spise ${ }^{9}$ použil spojení „píle ekonomické činnosti“10, či španělského jezuity Juana de Lugo, jež zmínil „chytrý ekonomický rozum“11. Bartolomeo Frigerio napsal roku 1629 spis L'economo prudente12, kde podle Schumpetera (1994) nalézáme zmínky o racionalitě lidského jednání. ${ }^{13}$

Bajka o včelách Bernada de Mandevilla ${ }^{14}$ vykresluje neřesti v lidském chování jako nutnost pro blaho společnosti. ${ }^{15}$ I zločinci jsou totiž užiteční. Je překvapivé, že právě Adam Smith, jenž je pokládán za zakladatele klasické ekonomie, řadí Mandevillův systém původu bohatství mezi systémy nemravné. „(...) úplně odstranil rozdíl mezi neřestí a ctností, a jehož snaha je naprosto zhoubná. (...) Člověk, všimá si Mandeville, má prirozeně mnohem větší zájem o své vlastní štěstí než o štěstí jiných a je nemožné, že by ve svém srdci mohl kdykoli dávat přednost jejich prospivání před svým vlastním. Kdykoli se zdá, že to dělá, můžeme si být jisti, že nás klame, a že tedy jedná na základě stejných sobeckých pohnutek jako kdykoli jindy." (Smith 2005, s. 323-324) Smith (2005) uznává nezpochybnitelný ohlas na Mandevillovo dílo a trefnou charakteristiku lidské povahy, která Mandevillově výkladu tvorby blaha společnosti dává za pravdu.

Adam Smith v Teorii mravních citů vykládá motivy lidského jednání mimo tržní struktury a v Bohatstoí národů poté principy fungování řádu trhu. První kapitola Teorie mravnich citů je uvedena větou: "At' již je dovoleno pokládat člověka za jakkoli sobeckého, přesto v jeho prirozenosti evidentně existují určité principy, které zpusobuji, že je zainteresován na osudu jiných lidí a že jejich štěstí je pro něj nezbytné, i když z něj nemá nic jiného kromě radosti, že je jeho svědkem." (Smith 2005, s. 5) Soucítění s jakýmkoli pohnutím mysli, tj. schopnost člověka vžít se do situace druhého prostřednictvím představivosti a prožívat s ním jeho emoce, je nazvána sympatií. Sympatie propojuje prvky společnosti a je zárodkem pro všeobecná pravidla spravedlnosti. Dobrotivé ctnosti, vedle nichž jsou ctnosti sebeovládání a sebezapření, vycházejí z „logiky srdce“, nikoli z utilitární

\footnotetext{
${ }^{9}$ Summa theologica moralis (1477)

${ }^{10}$ Udržujeme Janouškův překlad. Janoušek (2010, s. 4-5)

${ }^{11}$ Opět udržujeme Janouškův překlad. Janoušek (2010, s. 5)

12 Ze španělštiny název Frigeriova díla překládáme jako Rozumný správce.

${ }_{13}^{13}$ Předpoklad maximalizace slasti a minimalizace strasti se ve filosofickém myšlení objevuje již ve 4. st. př. n. l., a to v epikurejské etice, která za životní náplň považovala slast člověka.

${ }_{14}$ MANDEVILLE, B. (1997). The Fable of the Bees: Or Private Vices, Publick Benefits. Indianapolis: Hackett Publishing Company.

${ }^{15} \mathrm{~V}$ podobenství společnosti jakožto včelího úlu popisuje B. de Mandeville touhu lidí (včelek) po poctivé a spravedlivé společnosti. Bůh jejich přání vyslyší a z neřestných občanů se stanou poctivci. Avšak úl se nemění $\mathrm{v}$ blaho překypující společnost, je tomu právě naopak. Řemeslníci, kteří vyráběli zabezpečení domů, soudci, advokáti a další najednou přicházejí o práci. Z chování včelek vymizela touha po přepychu a luxusu, čímž strádají další odvětví. Konec včelího společenství je v bajce tragický. Přežije jen pár jedinců a i ti jsou z úlu vyhnáni jiným rojem včel. Bez neřesti, sobectví a nepoctivosti úl de facto vymřel.
} 
úvahy. (Pavlík 2004) Pravidla mravnosti vznikla dle Smitha spontánně, bez racionální utilitární úvahy a po jejich zafixování v lidské mysli jsou přírodou vtištěny jednotlivci jako zákony Boží. V Bohatství národů Smith mluví o sebezájmu jednotlivce, jež je v obchodních vztazích ctností účastníků směny, jehož nepředvídaným důsledkem je prosperita společnosti. Smith (2001) věří v přrirozený řád, který funguje samočinně a neviditelná ruka trhu koordinuje individuální úsilí jednotlivců pocházející z maximalizace vlastního prospěchu. V Bohatství národi̊ se Smith nezabývá podmínkami fungování trhu, nebot' předpokládá znalosti o mravním řádu z Teorie mravních citů.

J. S. Mill jako první použil termín economic man. (Blaug 1992) Citujeme slavnou pasáž, kde se tento pojem zrodil: "Věda začíná předpokladem, že člověk je bytost determinovaná, nutně ze své podstaty, preferovat v každém př́padě větši část bohatství před menši (...) Žádný politický ekonom však nikdy nebyl tak absurdní, že by předpokládal, že lidé jsou opravdu tak stavěni, ale (...) je to zpưsob, kterým věda musí nezbytně začít." (Mill 1967, s. 322) ${ }^{16}$ Mill neřekl, že bychom měli vzít skutečného člověka a odhadovat, jak se bude chovat $\mathrm{v}$ různých situacích a už vůbec ne, že skuteční lidé neustále maximalizují své bohatství. Ekonomie vybírá z lidského jednání pouze některé motivy, a to přesně motiv maximalizace bohatství (při omezení minimálními životními prostředky ${ }^{17}$ a potřebu volného času, přestože $\mathrm{v}$ lidském jednání bereme v úvahu i motivy neekonomické (zvyky a obyčeje), projevující se i v situacích, které spadají do rámce ekonomie. (Blaug 1992) Blaug Millovu aproximaci lidské bytosti nazývá fictional man.

Blaug (1992) datuje vstup předpokladu racionality lidského jednání do ekonomické vědy do 70. let 19. století, tj. do období marginalistické revoluce. Sirůček (1997) připisuje pojem homo economicus Williamu S. Jevonsovi. Jevons (1888) užíval matematického aparátu, jehož východiskem byl subjektivní užitek individua, který se jej snaží maximalizovat a zároveň minimalizovat strast. Hodnotu statků plně založil na užitku a politickou ekonomii pojal dle Sirůčka (1997) za „matematiku slastí a strastí“. Persky (1995) mylně připisuje první užití latinského termínu homo economicus V. Paretovi, a to v díle Manual of political economy (1906). Termín homo economicus se však objevuje již v díle Charlese S. Devase The Groundwork of Economics (1883).

A. Marshall ve svých Zásadách ekonomie předesílá, že lidské jednání má více aspektů než jen ty ekonomické, avšak ekonomie zkoumá pouze jednání, které je spojeno se získáváním a užíváním materiálních podmínek blahobytu individua. Člověk je ve svém rozhodování ovlivňován svým okolím, morálními pravidly i zvyky. Nelze správně podle Marshalla (1920) analyzovat ekonomické jevy, aniž by je ekonom

\footnotetext{
${ }^{16}$ Citace z anglicky psaných děl jsou přeloženy v celé práci do češtiny. Není-li uvedeno jinak, jedná se o autorské prreklady.

${ }^{17}$ Maximalizaci bohatství při co nejmenší újmě zformuloval také W. N. Senior jako jednu z hlavních tezí politické ekonomie. (Blaug 1992)
} 
nezasadil do sociálního a politického prostředí. Poznání lidského jednání je pro něj základem analýzy celé ekonomiky státu. Avšak v teorii spotřebitele předpokládá, že jedinec maximalizuje svůj užitek při preferencích, které se týkají pouze statků, o kterých je v daný okamžik rozhodováno. Preference jsou nezávislé jak na minulé, tak i na budoucí spotřebě a na spotřebě jiných osob. Pojaty jsou jako danosti.

Gary S. Becker aplikoval metodu mikroekonomické analýzy na doposud ekonomií neuvažované jevy. Za hlavní determinanty lidských preferencí Becker (1997) nepovažuje pouze biologické potřeby, ale také zvyky, kulturní prostředí, zkušenosti (osobní kapitál) a společenské okolí (společenský kapitál). Ačkoli předpokládá, že jednotlivci maximalizují užitek, a to konzistentním zpơsobem, připouští, že mohou mít nedokonalou pamět', budoucnost až př́liš diskontovat, či se mohou mýlit, jejich rozhodování může být závislé na formulaci problému nebo ovlivněno návykovou látkou. Chování, které Becker (1997) analyzuje, přesto nazývá racionální. Osobní kapitál zahrnuje spotřebu v minulosti, minulé zkušenosti, vzdělání a budoucí užitky, které determinují současnou spotřebu (rozhodnutí), a společenský kapitál absorbuje relevantní chování příslušníků referenční skupiny. U drogově závislých jedinců rozšiřrená užitková funkce dokáže uchopit jejich závislost s ohledem na minulou spotřebu a u podnikatele zaměstnávajícího neschopného synovce „jiný pohled“" na synovce jako svého zaměstnance. ${ }^{18}$

Rozšířená užitková funkce má tvar: $u=u(x, y, z, P, S), \quad$ kde $x, y, z$ jsou množství „standardních“ statků. ${ }^{19}$ Pro daného jednotlivce zůstává formálně užitková funkce konstantní po dobu jeho života (ve smyslu determinace množství standardních statků proměnnými P a S), ačkoli osobní i společenský kapitál se mění. Navíc funkce má univerzální charakter, nebot' dokáže zahrnout i odlišné kulturní zvyklosti. Problémem však zůstává, jak rozšǐřenou užitkovou funkci v reálné podobě zkonstruovat a následně uplatnit v predikci chování jedince ekonometrický aparát.

Becker neodmítá předpoklad maximalizace užitku, tvrdí, že i drogově závislí i podnikatel s neschopným synovcem jednají racionálně, ale objektem jejich

18 Rothbard (cit. Pavlík 2004) demonstruje na př́kladu podnikatele zaměstnávajícího svého neproduktivního synovce nemožnost aplikace ekonomické teorie. Podnikatel maximalizuje svůj psychický profit na úkor svého peněžního profitu. Predikovala-li by neoklasická ekonomie jeho jednání, počítala by, jako kdyby maximalizoval svůj zisk, tj. synovce by ve své firmě podnikatel nezaměstnal. Predikce je však chybná nejen z důvodu, že tak v realitě zaměstnavatel nečiní, ale subjekt tak nečiní ani as-if. Navíc, jestliže synovec zastává důležitou pozici $\mathrm{v}$ rámci struktury podniku, je velmi pravděpodobné, že by kvưli jeho chybným rozhodnutím podnik v dlouhém období skončil. Ani tento fakt by neoklasická ekonomie nedokázala předpovědět. Podnikatel však své jednání může $k$ předpokládanému racionálnímu přiblížit tím, že synovce uplatní na méně důležité pozici, odkud neefektivní činnost výrazně nenaruší systém podniku. Za těchto okolností podnik na trhu přežije a bude dosahovat uspokojivého zisku. Jelikož neoklasická ekonomie předpokládá as-if univerzálnost agentů, její modely nezahrnují vliv institucí, které se v rámci kultur liš́i.

${ }^{19}$ Užíváme zjednodušeného zápisu jako Pavlík (2004, s. 747). 
maximalizace je rozšǐřená užitková funkce. ${ }^{20}$ "Začleňuje takto i iracionální "šílence" do univerzality lidstoí." (Pavlík 2004, s. 750) Lidský kapitál je u Beckera měřitelná veličina, která umožňuje empirické testování modelů s rozšîřenou užitkovou funkcí.

\section{Neoklasická ekonomie jako pozitivní věda}

Neoklasická ekonomie se opírá o metodologický pozitivismus. Je nezávislá na jakýchkoli normativních soudech a etických pozicích. Podle Friedmana (1997) může být ekonomie objektivní stejně, jako jsou objektivní i prrírodní vědy. Za hlavní úkol pozitivní vědy je pokládán vývoj teorií, které poskytují hodnotné a smysluplné předpovědi. ${ }^{21}$ Jediným relevantním testem platnosti hypotézy je pak srovnání jejích předpovědí se skutečností. Shodu předpokladů modelu $s$ realitou, jakožto test platnosti modelu, považuje Friedman za zásadně chybný názor způsobující mnoho škod. Předpoklady pozitivní ekonomie neříkají, jak se člověk skutečně chová, pouze jeho rozhodování chápe tak, jako kdyby maximalizoval svůj užitek (výrobce zisk). Co se týče nemožnosti provádění řízených experimentů ve společenských vědách, nepokládá tento "problém" Friedman za hlavní odlišnost mezi sociálními a fyzikálními vědami. Neřízená zkušenost se od řízeného experimentu liší podle jeho slov pouze ve stupni.

„Ekonomie jako pozitivní věda je tělesem zkusmo prĭjatých zevšeobecnění o ekonomických jevech, která mohou být používána pro předvídání následků změn okolností." (Friedman 1997, s. 14) Pro vysvětlení jevu konstruujeme modely s různými alternativními soubory předpokladů. Výběr mezi nimi provádíme na podkladě predikční schopnosti, úspornosti, jasnosti a přesnosti. (Friedman 1997)

Výrobcův cíl je maximalizace zisku, avšak jak k němu výrobce dospívá (výrobcovy matematické schopnosti), neoklasická ekonomie neřeší. Pokládá je za dané a o schopnostech výrobce nepřemýšlí. Tento „nedostatek“ je vysvětlen předpokladem "as-if". Neoklasická ekonomie neříká, že člověk je schopen ve své hlavě zvládnout spočítat soustavu rovnic o mnoha neznámých a zjistit bez nákladů optimální výsledek

\footnotetext{
${ }^{20}$ Becker odmítá pojetí klasické pojetí racionality jako vhodnost prostředků k cíli: „Racionalita je obecně definovaná jako efektivní použivání prostředků k dosažení nějakého cíle. Chování, které je racionální, obsahuje dva prvky: prostředky a cíle. Nemůžete hovořit o racionalitě cílů. To můžete udělat pouze $\mathrm{v}$ prŕpadě, že přeměníte konečný cíl na pouze přechodný cíl $\mathrm{k}$ dosažení něčeho jiného. Je pro někoho např́iklad racionální kouřit? Záleží, jak se na to podíváte. Jestliže někdo bere do úvahy náklady kouření, uvažuje-li jistou pravděpodobnost zkrácení svého života, a přesto je ochoten platit tuto cenu, nemůžete říci, že je pro něj kouření iracionální. Mưžete se ale ptát dále. Jestliže předpokládáme, že onen člověk kouří pro potěšení, dělá to tím nejefektivnějším a nejlevnějším zpưsobem? A tady přichází na řadu racionalita, a tedy hledání toho nejefektivnějšího a nejlevnějšího. Na druhou stranu když řeknete, že vaším konečným cílem není potěšení $z$ kouření, ale co nejdelší život, pak můžete argumentovat tím, že kouření je iracionální. Myslím si proto, že racionalitu nemůžete definovat bez ohledu na zvolený cíl, při jehož sledování se snažíte jí porozumět.“ (Pavlík, ed. 1998, s. 66 - 67.)

21 Předpovědi Friedman nechápe pouze ve smyslu předpovědi budoucích událostí, ale také jako predikce minulých dějů.
} 
(a že tak v reálném životě činí), pouze tvrdí, že s lidským chováním pracuje a počítá tak, jako kdyby výrobce ve své hlavě optimalizoval. Stejně je tomu v teorii spotřebitele. Chování jednotlivců analyzuje tak, jako kdyby maximalizovali svůj užitek při různých druzích omezení.

\subsection{Povaha dat}

Neoklasická ekonomie pracuje pouze s daty o výsledcích rozhodovacího procesu, nebot' zvnějšku lze pozorovat pouze vybrané volby a nikoli průběh $v$ mysli, tj. jak a proč se $\mathrm{k}$ volbám dospělo, a proto $\mathrm{v}$ zásadě datům o výsledcích rozhodování přisuzujeme objektioní povahu. Jak subjekt ke zvolené alternativě dospěl (co se odehrálo $\mathrm{v}$ jeho mozku, proč volil zrovna určitou možnost), není pro ekonoma důležité. Výsledky voleb jsou navíc často měřitelné (např. celková spotřeba určitého statku), či se dají v modelu nahradit kvalitativními proměnnými (např. volba druhu bydlení).

Data o fungování lidské mysli během procesu rozhodování mají jiný charakter. Hayek (1995) charakter dat společenských věd pokládá za subjektivní. „Od faktů př́rodních věd se liší tím, že jsou to přesvědčení nebo názory určitých lidí, přesvědčeni, která jako taková jsou našimi daty bez ohledu na to, zda jsou pravdivá nebo nepravdivá, a která navic nemůžeme pozorovat prímo v hlavách lidi, nýbrž můžeme je poznávat jenom v tom, co lidé dělají a řikají, a sice pouze proto, že myšlení nás samotných je podobné jejich myšlení." (Hayek 1995, s. 29) Kdybychom byli s to pochopit dokonale fungování lidského mozku (proč lidé volí tak, jak volí), data by měla objektivní povahu. Jelikož dokonalého pochopení rozumu nebylo doposud dosaženo, data jsou subjektioní. ${ }^{22}$ Metodou jejich získávání je především introspekce, dotazníkové průzkumy, rozhovory či behaviorální experimenty.

\subsection{Testovatelnost hypotéz}

Žádnou hypotézu v univerzálním tvaru „pro každé x platí y“ nemůžeme podle K. R. Poppera (1997) verifikovat. Verifikace je možná pouze u existenciálních tvrzení, jež mají tvar „existuje alespoň jedno x, pro které platí y“. Naopak falsifikovat univerzální hypotézy lze nalezením jediného příkladu, pro nějž tvrzení neplatí. Existenciální hypotézu naopak falzifikovat nelze. Neoklasickou hypotézu o racionálním jednání ve tvaru: „Ekonomický subjekt vybírá z možných a jemu známých

\footnotetext{
22 „Tyto výrazy [subjektivní a objektivní] jsou však dvojznačné a bez dalšiho vysvětlení se mohou ukázat jako zavádějicí. Zatímco pro prírodovědce je protiklad mezi objektivními fakty a subjektivními miněními něčím zcela jednoduchým, nelze tento prédpoklad tak snadno aplikovat na předmět společenských věd. To má dũvod $v$ tom, že předmětem neboli "fakty" společenských věd jsou také minèní - samozřejmě že nikoli minèní toho, kdo společenské jevy zkoumá, nýbrž minèni těch, jejichž činnost je predmětem poznávání. V určitém smyslu jsou tato fakta stejně málo "subjektioní" jako fakta př́rodních věd, protože jsou nezávislá na jednotlivém pozorovateli; předmět jeho zkoumání není determinován jeho zálibou nebo imaginací, nýbrž stejným způsobem je dán i pro jiné pozorovatele." (Hayek 1995, s. 29)
} 
alternativ vždy tu, ze které očekává nejvyšší užitek." Popperovsky vyvrátíme (falsifikujeme) nalezením subjektu, který zvolí možnost, která mu nepřináší maximální možný užitek. Zde však vzniká otázka, zdali je pozorovatel vůbec schopen zjistit, zda subjekt maximalizoval užitek, nebot' ten je ryze subjektivní.

Hypotézy o průběhu rozhodovacího procesu (co se děje v mysli, než dojde $\mathrm{k}$ pozorovatelnému rozhodnutí) ověřujeme pomocí subjektivních dat. Ačkoli v behaviorálních experimentech získáváme určitá data a z vyjmenovaných metod jsou nejblíže objektivní povaze, nelze závěry vztáhnout s nutnou platností na reálné rozhodování aktérů. Důležitým metodologickým závěrem pro předkládanou práci je tedy fakt, že tvrzení o tom, jak se lidé rozhodují (tj. samotné předpoklady modelu homo economicus) nelze ověřit, nebot' pozorovatel není schopen rozpoznat jednání subjektu jakožto maximalizační. Nelze tedy zodpovědět otázku, zda je pravdou, že člověk maximalizuje svůj užitek atp.

Proto Milton Friedman odmítl připustit, že model může být odmítnut $z$ důvodu nerealističnosti jeho předpokladů. Jejich pravdivost totiž nelze přesně testovat. ${ }^{23}$ Nabízí se však logická otázka, zdali důvod falzifikace předpovědi modelu nemohou mít na svědomí právě nerealistické či prostě chybné předpoklady.

\section{Omezená racionalita}

Termín omezená racionalita prvně použil Herbert Simon. ${ }^{24}$ Ekonomickou veřejnost přesvědčil, že se lidé vždy nechovají jako racionální bytosti, se kterými je uvažováno v modelech racionálního chování. ${ }^{25}$ Neoklasický model homo economicus "slouží snad jako model mysli Boha, ale jistě ne jako model mysli člověka" (Simon 1983, s. 34). Subjekt nutně nehledá optimální řešení donekonečna, ale proces hledání zastaví v okamžiku, kdy nalezne řešení uspokojivé (nikoli optimální). Následovníci Simonova díla se ustavili v rámci behaviorální ekonomie, jejíž zkoumání je silně ovlivněno pracemi psychologů Daniela Kahnemana a Amose Tverskyho. V rámci behaviorální ekonomie je pracováno s koncepcí kognitioní nedokonalosti v racionalitě subjektu, která zohledňuje systematické zanášení omylů a chyb do rozhodovacích procesů. Behaviorální

\footnotetext{
${ }^{23}$ Boland (2004) navíc podotýká, že v předpokladu není jasně řečeno, co je objektem maximalizace. Jeli hypotézou, že všichni lidé (něco) maximalizují, lze ji falzifikovat nalezením protipř́íkladu, kdy člověk nic maximalizovat nebude. Avšak odkud bereme jistotu, že tento člověk opravdu nic nemaximalizoval? Falsifikace hypotézy „Existuje alespoň jeden člověk, který nemaximalizuje.” z důvodu jejího existenciálního charakteru není možná.

${ }^{24}$ Za předchůdce behaviorální teorie firmy pokládá Simon (1997) institucionalismus J. R. Commonse. ${ }_{25}$ "Model subjektivního očekávaného užitku prédpokládá, že rozhodující agent zváží v jedné komplexní prèdstavě vše, co před ním leží. Rozumí souboru alternativních voleb, jež má $k$ dispozici nejen $v$ daném okamžiku, ale $i$ na horizontu budoucnosti. Rozumí následkưm každé z dostupných možností - přinejmenším v takové míre, že je schopen přriradit spojité pravděpodobnostní rozdělení k budoucím stavuim světa. Usmíril či vyrovnal všechny si odporující mezní hodnoty a spojil je do jednoduché užitkové funkce, která podle jeho preferencí uspořádává budoucí možné stavy světa." (Simon 1983, s. 13)
} 
poznatky získané z výsledků experimentů odlišující se od predikce neoklasické ekonomie se model homo economicus nesnaží popírat, ale zasadit jej do reálného kontextu (např. Kahneman 2003). ${ }^{26}$

V první kapitole jsme přehledně vyjmenovali předpoklady teorie subjektivního očekávaného užitku. Teorie omezené racionality tři z nich zmírňuje a nahrazuje je prvky uspokojivé volby namísto volby optimální. Předpoklady SEU teorie modifikuji podle Simona (1997) následujícími požadavky:

1. správně definovanou užitkovou funkci jako předpoklad zanecháváme (kardinalitu však odmítáme);

2. neměnnou přípustnou množinu známých alternativ nahrazujeme teorií, která popisuje proces vytváření možných voleb (Hayekova teorie lidské mysli);

3. namísto znalosti pravděpodobnostního rozdělení následků každé alternativy zavádíme odhadovací proces jednotlivce, který znalost pravděpodobností nepředpokládá;

4. maximalizaci užitkové funkce nahrazujeme předpokladem uspokojivé volby, resp. rozhodovací strategií vedoucí k uspokojivému výsledku (Simon 1997 užívá termín satisficing strategy).

Omezenou racionalitu nikdy nelze ztotožňovat s iracionálním chováním. Omezená racionalita znamená rozhodování na základě optimálně získaného souboru dostupných relevantních informací a od „neoklasické“ racionality se liší ve znalosti alternativ. Omezená racionalita uvažuje nedokonalou znalost všech alternativ, jelikož proces zjišt'ování všech alternativ je př́liš dlouhý a nákladný. Uspokojujicí strategie vede k nalezení volby, která splňuje více kritérií a subjekt nezatěžuje složitým a často nezvladatelným procesem hledání řešení. ${ }^{27}$ Rozhodovací subjekt si vytvoří určitou aspiraci, pro jak vhodnou alternativu by se měl rozhodnout. Jakmile objeví možnost odpovídající úrovni aspirace, ukončí vyhledávání a možnost zvolí. SEU teorii lze vyvrátit pouze nalezením alternativy vysvětlující rozhodování subjektů. Nelze se opřít o fakt, že lidé neprovádí maximalizační propočty $\mathrm{v}$ reálné situaci, jelikož to neoklasická ekonomie nikdy netvrdila. Musí být prokázáno, že se ekonomičtí

\footnotetext{
${ }^{26}$ Behaviorální ekonomie je charakteristická propojením poznatků psychologie a ekonomie. Nicméně cíle zmíněných věd jsou odlišné, jak tvrdí Levine (2012). Psychologie si dává za cíl zkoumat jedince, zatímco ekonomie zkoumá spíše jednání většího množství lidských bytostí (popř. firem), zvláště pak jejich interakce.

27 Rozhoduji-li se o návštěvě restaurace, jistě budu zvažovat cenu jídla a pití, př́iemnost obsluhy, odhadovaný počet volných míst, kuřácké/nekuřácké prostředí, vzdálenost, možnost zaparkování atd. Pokud restaurace vyhovuje všem požadavkům, nebudu chtít získávat informace o jiných provozovnách. Vybraná restaurace nemusí představovat optimální výběr, ale uspokojivý určitě ano.
} 
aktéři nechovají ani tak, jako kdyby maximalizovali. Odchylkami od as-if maximalizačního chování se zabývá behaviorální ekonomie. ${ }^{28}$

\subsection{Poznatky behaviorální ekonomie}

Behaviorální ekonomie ve svých experimentech testuje predikce neoklasického modelu homo economicus. V experimentech bylo zjištěno, že predikční schopnost neoklasického modelu je v určitých případech slabá. Lidé kalkulují s utopenými náklady či se nechají ovlivnit zarámováním problému. Behaviorální ekonomové se snaží vysvětlit důvody iracionálního chování a rozšířit model člověka o další předpoklady, které vylepšují jeho predikční schopnost.

Model racionální volby pracuje s tvrzením, že bohatství je zastupitelné. Kahneman a Tversky (1981) zastupitelnost bohatství vyvracejí. Při pokusu bylo jedné skupině lidí řečeno, at' si představí, že si za 10\$ koupili lístek do divadla a při cestě na představení tento lístek ztratili. Druhá skupina lidí si měla představit, že jdou na představení s tím, že si lístek koupí až na místě, avšak cestou jim z peněženky $10 \$$ vypadne. V obou skupinách se pak dotazovali, zda na představení přeci jen půjdou. V opakovaných pokusech bylo zjištěno, že $54 \%$ účastníků z první skupiny by na představení nakonec nešlo, zatímco $88 \%$ z druhé skupiny by si lístek i přes ztrátu $10 \$$ zakoupilo. Ztráta vstupenky v hodnotě $10 \$$ by měla mít však stejný účinek jako ztráta 10\$.

Dalším z tvrzení, které vyplývá z teorie racionální volby a bylo Kahnemanem a Tverskym (1981) zpochybněno, je hodnocení událostí podle výsledného vlivu na celkové bohatství. Užitek je rostoucí funkcí celkového bohatství, a proto v případě, že člověk získá darem 100\$ a následně ztratí (či je nucen zaplatit) 80 , si oproti původní situaci, kdy 100\$ ještě nezískal, ani 80\$ ještě neztratil, polepší (jeho užitek v nové situaci je vyšší). Kahneman a Tversky zjistili, že lidé přikládají větší váhu ztrátě peněz než zisku. Tento jev vysvětlují pomocí oceňovací funkce (value function), definované pro změny bohatství, nikoli pro celkové bohatství. Oceňovací funkce má konkávní tvar v ziscích, konvexní ve ztrátách. ${ }^{29}$

Podle modelu racionální volby ekonomický subjekt ignoruje utopené náklady. Thaler (1980) ukazuje, že lidé naopak velmi často utopené náklady do svého rozhodování zahrnují. Jeho „pizza experiment“ ukázal, že lidé, kteří přišli na oběd, při kterém mohli sníst tolik, kolik pizzy chtěli, a zaplatili za něj určitou částku, snědli

\footnotetext{
${ }^{28} \mathrm{~K}$ rozdílům mezi metodologií behaviorální ekonomie a teorie racionální volby viz např. Špecián (2012).

${ }^{29}$ Viz Kahneman \& Tversky (1981).
} 
kusů pizzy více než ti, kteří přišli za stejnou nabídkou obědu, ale než si začali objednávat, cena oběda jim byla vrácena. ${ }^{30}$

Behaviorálními ekonomy bylo zjištěno, že i když člověk dokonale zná veškeré potřebné informace, nezřídka v rozhodnutích selhává, tj. volí iracionálně. Často se navíc mýlí systematicky, a nikoli náhodně. Kahneman a Tversky (1974) identifikovali heuristiky (pravidla „rozhodování od oka“), jimiž se lidé řídí. ${ }^{31}$

\section{Predikční schopnost modelu}

Neoklasické modely poskytují v určitých případech správné predikce. Například sníží-li se úrokové míry $u$ hypotečních úvěrů, ceteris paribus se zvýší objem poskytnutých hypotečních úvěrů. Postihne-li moravské vinohrady nevlídné počasí, ceteris paribus cena moravského vína poroste atd. Přijmeme-li Simonovu teorii omezené racionality v jednání ekonomických agentů, pak se nabízí otázka, jak mohou neoklasické modely dobře predikovat, ačkoli stojí na nerealistických předpokladech. Jak je možné, že se reální jedinci opravdu chovají, jako kdyby odpovídali předpokladům modelu homo economicus?

Jelikož se ekonomie zabývá lidským jednáním, je nutnou podmínkou, aby ekonomický aktér existoval. Dále proto budeme abstrahovat od sebevražedného chování agentů a budeme pokládat za lidský primární motiv snahu přežít. Výsledkem biologické evoluce je rozumně myslící lidská bytost. Přímé ohrožení života ze strany přírody v současné době nehrozí, nicméně boj o přežití neustal. ${ }^{32}$ Jen se přesunul do ekonomicko-společenského prostředí, tj. na trh se statky různých druhů. Nemusí se jednat jen o trhy s materiálními statky, trh práce atp., ale i o trhy např́klad $\mathrm{s}$ potenciálními partnery. Biologické znaky se mění $\mathrm{v}$ řádu tisíciletí, oproti tomu vzorce chování se mění rychleji, řekněme v řádu desetiletí. V průběhu kulturní evoluce dochází k expanzi těch kultur, jejichž chování je efektivnější, umožňuje prosperitu a rozmnožování svých členů, na úkor méně efektivně jednajících společenství,

\footnotetext{
30 Skupina lidí, kterým byla cena oběda vrácena, byla vybrána náhodně. Proto se nelze domnívat, že zrovna tito lidé měli pizzu rádi méně (či měli méně roztažené žaludky) než skupina, kterým cena obědu vrácena nebyla.

31 „[Heuristika] redukuje složité úlohy $v$ oblasti odhadování pravděpodobností a předpovídání hodnot na jednodušši rozhodovací operace. Obecně jsou ty to heuristiky velmi užitečné, ale někdy mohou vést $k$ vážným a systematickým chybám" (Kahneman \& Tversky 1974, s. 1124). Např.: Vybavitelnost určitých př́kladů v paměti nás vede $\mathrm{k}$ odhadování četnosti výskytu určité události. Čím lépe si příklady vybavíme, tím více se o nich domníváme, že se vyskytují s vyšší frekvencí. Reprezentativní heuristika vede k mylnému odhadování pravděpodobnosti, že prvek $X$ je součástí množiny $Y$, nebot' je odhadována na základě úvahy, do jaké míry X splňuje obecné charakteristiky prvků z množiny Y. Kotevní heuristika způsobuje odhad hodnoty určité veličiny závislý na určité počáteční hodnotě (výchozím bodu) jakéhokoli původu. 32 Vyjma přirodních katastrof, kvůli kterým vědci pracují na softwarech, jež by je dokázaly predikovat.
} 
která vymírají či se podrobují. ${ }^{33}$ Chce-li neoklasický model předpovědět jednání obyvatel se zažitými kulturními a náboženskými zvyklostmi, musí tyto charakteristické kulturní znaky zanést i do svých předpokladů.

\subsection{Důvody přežívání neefektivních subjektů na trhu}

Jelikož v kulturní evoluci přežívají efektivněji strukturované společnosti, pokládáme si otázku, jak je možné, že i omezeně racionální subjekt je schopen v rámci tržního hospodářství přežít. Nemají jedinci, kteří jsou „neomezeně“ racionální,34 v dosahování svých cílů výhodu, resp. nejsou v na trhu úspěšnější? Důvodem je jednak nenáročnost na informace, ve druhém případě se jedná o metodu imitace úspěšnějších subjektů.

Cena v sobě nese informaci, která je často dostatečná pro optimalizační (nebo jemu se blížící) rozhodování. Avšak subjekty, které jsou si vědomy, že ceny na trhu nenesou dostatečně všechny informace, mají výhodu. Subjekty, které dokážou včas předvídat vývoj cen a včas rozpoznávají, že ceny neodpovídají „reálnému dění“, přežívají a v konkurenčním boji vítězí.

Druhým vysvětlením, proč se tržní subjekty chovají podle predikcí modelu homo economicus, je jejich imitační chování. Alchian (1950) tvrdí, že úspěch v tržním prostředí závisí pouze na výsledcích, nikoli na motivacích. Výrobce nemusí nutně maximalizovat zisk, stačí, aby se výsledek jeho podnikání nepropadl do červených čísel. Kladného zisku podle Alchiana (1950) výrobce dosahuje náhodnou metodou, tj. ve smyslu omezené racionality, metodou pokus-omyl. Alokace zdrojů i v případě nahodilého jednání subjektů neprobíhá nahodile; zdroje jsou přesouvány vždy od méně efektivních aktérů k efektivnějším.

Metoda pokus-omyl je však metodou nákladnou a zdlouhavou. Stejně tak nákladné je i snažení se o získávání všech informací a nalézání všech dostupných alternativ a následný optimalizační proces. Proto je vhodnější (ve smyslu méně nákladné) inspirovat se ve svém jednání u úspěšnějších konkurentů. Imitace jednání efektivnějších subjektů pomáhá přežít na trhu i s omezenou racionalitou.

Poprvé se tedy subjekty učí z vlastních chyb (metoda pokus-omyl), podruhé se učí od úspěšnější konkurence. Je logické, že napodobovány jsou vždy nejúspěšnější formy jednání, tedy ty, které se budou nejvíce přribližovat „neomezené" racionalitě předpokládané modelem homo economicus. Evoluční vysvětlení de facto racionálního jednání subjektů vede k závěru, že na trhu se po delší dobu nemohou udržet subjekty

\footnotetext{
33 Analogii ke kulturní evoluci nalezneme i v teorii firmy při dokonalé konkurenci na trhu. Je-li firma neefektivní, postupně dojde $\mathrm{k}$ jejímu zániku, nebot' její efektivnější konkurenti jí nenechají žádné zákazníky.

${ }^{34}$ Nebo se alespoň $\mathrm{k}$ "neomezené“ racionalitě velmi přibližují.
} 
s neefektivními vzorci chování. Avšak v realitě tomu tak není. Ačkoli například firma odmítá soustavně zaměstnávat př́islušníky menšiny, z trhu není nucena odejít.

\section{2. „Nedokonalé“ vyčišt'ování trhů}

Neoklasická ekonomie předpokládá, že se v dlouhém období trhy vyčištúují, tzn. že „odpadávají“ subjekty, které neefektivně jednají, a přežívají subjekty efektivní. Prvním vysvětlením, proč na trhu přežívají i agenti s omezenou racionalitou, je „nedostatečný“ tlak konkurence. Jakmile subjekt zjistí, že uspokojivá volba nezpůsobila vážné ohrožení či újmu, nemá důvod své chování měnit. Stačí, aby se okolnímu prostředí subjekty přizpůsobily tak, aby si zajistily uspokojivou životní úroveň. "Odpadlíci“ jsou pak ti, kteří se přizpůsobili méně a jednali méně uspokojivě. Vysvětlením dostatečnosti v rozhodování je fakt, že optimální rozhodnutí lze nalézt pouze pro daný časový okamžik. Prostředí, ve kterém subjekt jedná, se neustále proměňuje, a proto ani nelze nalézt $\mathrm{v}$ realitě dokonalé vzorce chování, které by poskytly nekonečně optimální volby. Je nutné se uchýlit k uspokojivým volbám.

Neefektivní prvky přežívají také z důvodu existence společenského prostředí, které je formováno normami, zvyky a tradicemi. Jednání $\mathrm{v}$ tomto prostředí je determinováno institucemi. Některé tradice se mohou jevit jako neefektivní, např. muslimská modlitba pětkrát denně, avšak dodržují-li tento zvyk i ostatní subjekty na trhu, neefektivní zvyk nebude evolucí z jednání subjektů vytlačen. Rigidita institucí je dána vysokými transakčními náklady na jejich přeměnu, jež by dovolila posunout jednání agentů směrem $\mathrm{k}$ „neomezenému“ racionálnímu jednání.

\section{Závěr}

Pro zkoumání oprávněnosti, platnosti či překonanosti modelu homo economicus bylo nejprve nutné předpoklady modelu jasně definovat. Výčet předpokladů jsme opřeli o práce H. Simona a A. Etzioniho. Neoklasický model aproximuje lidské jednání jako jednání dokonale informovaného jedince, jež se vždy racionálně rozhoduje podle analýzy nákladů a užitků. Své cíle uspokojuje podle jejich postavení v hodnotovém žebříčku. Vždy jako první uspokojuje nejžádanější cíl. Ve svém rozhodování není ovlivněn žádnými heuristikami nebo institucemi či minulou zkušeností.

Nezbytně nutné bylo pojednat o metodologii, kterou využívá neoklasická ekonomie, a to jednak $\mathrm{z}$ důvodu určení oprávněnosti kritiky modelu, a také pro vytyčení cesty k možnému zdokonalení predikčních schopností modelu. Jelikož podle pozitivistické metodologie nelze kritiku modelu obrátit $\mathrm{k}$ jeho předpokladům, ale pouze $\mathrm{k}$ jeho predikcím, které lze porovnat s realitou a na základě porovnání ŕíci, zda model je oprávněný či nikoli, za relevantní kritiku modelu jsme pojali pouze tu, která 
dokazuje, že neoklasická teorie předvídá v rozporu s realitou. Otázka, zda se lidská bytost chová, či nechová podle předpokladů člověka ekonomického, v práci zodpovězena nebyla kvůli subjektivnímu charakteru užitku. Pozorovatel nemůže říci, zda subjekt užitek maximalizuje, potažmo zdali vůbec něco maximalizuje. Tvrzení, že modifikace předpokladů vede ke kvalitnějším predikcím, bylo doloženo na výsledcích experimentů behaviorální ekonomie, i za vědomí, že výsledky experimentů nemusejí nutně souhlasit s reálným jednáním aktérů.

Beckerova rozšǐřená funkce užitku je schopna zahrnout i společenský a osobní kapitál, které rozhodování jedince, jakožto součást společenské struktury, ovlivňuje. Pomocí ní lze navíc predikovat i smrt subjektu způsobenou neustálým uspokojování svých potřeb prostřednictvím nejlepších možných prostředků.

Důvody slabé predikční schopnosti modelu byly zdůvodněny heuristikami lidského jednání a jeho ovlivněním společenským rámcem, ve kterém se udržují určitá pravidla a zvyky. Teorie omezené racionality, popírající maximalizační jednání subjektů, nahradila maximalizační strategii strategií uspokojovací, která posouvá předpoklady modelu homo economicus blíže k reálnému chování jedinců. Behaviorální ekonomie prostřednictvím experimentů pak definovala heuristiky lidského jednání, které jej odchylují od predikcí neoklasické ekonomie. Model homo economicus nebyl behaviorální ekonomií nahrazen alternativní aproximací, která by byla schopna lépe predikovat. Předpoklady lidského jednání byly pouze rozšiřreny o dodatečné determinanty.

Model však predikuje $\mathrm{v}$ mnohých situacích kvalitně. Tento jev byl zdůvodněn jednak nízkými náklady na získávání informací (jelikož jsou obsaženy v ceně) a tedy snadnější optimalizační rozhodování, a také imitačním chováním ze strany méně efektivních subjektů.

V práci byla odmítnuta překonanost modelu a byly vytyčeny směry, kterými se může ubírat jeho kritika a snaha o zdokonalování jeho predikční schopnosti. Rozšřření předpokladů nejen o realističtější prvky jednání lidského individua zkvalitňuje predikce neoklasického modelu homo economicus. 


\section{Bibliography}

ALCHIAN, A. 1950. Uncertainty, Evolution, and Economic Theory. The Journal of Political Economy. 1950, Vol. 58, No. 3, pp. 211-221.

BECKER, G. 1997. Teorie preferencí. Praha: Grada Publishing, 1997, 350 stran. ISBN 80-7169-463-0.

BLAUG, M. 1992. The methodology of economics: Or how economists explain. 2nd edition. Cambridge: Cambridge University Press, 1992, 286 stran. ISBN 0-521-436788.

BOLAND, L. A. 2004. The Principles of Economics: Some Lies My Teachers Told Me. London: Rouledge, 2004, 233 stran. ISBN 0-415-13208-8.

ETZIONI, A. 1995. Morální dimenze ekonomiky. Praha: Victoria Publishing, 1995, 243 stran. ISBN 80-85865-19-X.

FRIEDMAN, M. 1997. Metodologie pozitioní ekonomie. Praha: Grada Publishing, 1997, 20 stran. ISBN 80-7169-521-1

HAYEK, F. A. 1995. Kontrarevoluce vědy. Praha. Liberální institut, 1995, 212 stran. ISBN 80-85787-87-3.

HLAVÁČEK, J. 1999. Mikroekonomie sounáležitosti se společenstvím. Praha: Nakladatelství Karolinum, 1999, 207 stran. ISBN 80-7184-856-5.

JANOUŠEK, J. 2010. Homo economicus jako psychologický problém. Pražské sociálně vědní studie. 2010, Psychologická řada PSY-028.

JEVONS, W. S. 1888. The Theory of Political Economy. 3rd edition. London: Macmillan and Co.

KAHNEMAN, D.; TVERSKY, A. 1974. Judgement Under Uncertainty: Heuristics and Biases. Science. New Series. 1974, Vol. 185, No. 4157, pp. 1124-1131.

KAHNEMAN, D., TVERSKY, A. 1981. The Framing of Decisions and the Psychology of Choice. Science. 1981, Vol. 211, Iss. 4481, pp. 453-458.

KAHNEMAN, D. 2003. Maps of Bounded Rationality: Psychology for Behavioral Economics. The American Economic Review, Vol. 93, No. 5, pp. 1449-1475.

KALBERG, S. 1980. Max Weber's Types of Rationality: Cornerstones for the Analysis of Rationalization Processes in History. The American Journal of Scoiology. 1980, Vol. 85, No. 5, pp. 1145-1179. 
LEVINE, David K. (ed.). 2012. Is Behavioral Economics Doomed?: The Ordinary Versus the Extraordinary. Open Book Publishers.

MARSHALL, A. 1920. Principles of Economics. 8th edition. London: Macmillan and Co., Ltd.

MILL, J. S. 1967. Essays on Economics and Society. London: Routledge \& Kegan Paul. 847 stran.

PAVLÍK, J. 2004. F. A. Hayek a teorie spontánního řádu. 1. vyd. Praha: Professional Publishing, 2004, 805 stran. ISBN 80-86419-57-6.

PAVLÍK, J., ed. 1998. Milton Friedman v Praze: myšlenky, názory, komentáře. Praha: Liberální institut a GRADA Publishing, 1998, 103 stran. ISBN 80-7169-639-0.

POPPER, K. R. 1997. Logika vědeckého zkoumání. Praha: OIKOYMENH, 1997, 617 stran. ISBN 80-86005-45-3.

SCHUMPETER, J. A. 1994. History of Economic Analysis. London: Routledge, 1994, 1260 stran. ISBN 0-415-10888-8.

SIMON, H. A. 1983. Reason in Human Affairs. Stanford: Stanford University Press, 1983, 115 stran. ISBN 0-8047-1848-2.

SIMON, H. A. 1996. The Sciences of the Artificial. London: Massachusetts Institute of Technology Press, 1996, 231 stran. ISBN 0-262-19374-4.

SIMON, H. A. 1997. Models of Bounded Racionality - Volume 3 (Empirically Grounded Economic Reason). London: Massachusetts Institute of Technology Press, 1997, 457 stran. ISBN 0-262-19205-5.

SIRU゚ČEK, P. 1997. Ekonomický člověk jako základ moderní ekonomie (vybrané problémy). Marathon. 1997, č. 3, pp. 5-15.

SMITH, A. 2001. Pojednání o podstatě a pưvodu bohatství národů. Praha: Liberální institut, 2001, 986 stran. ISBN 80-86389-15-4.

SMITH, A. 2005. Teorie mravních citů. Praha: Liberální institut, 2005, 460 stran. ISBN 80-86389-38-3.

STEELE, G. R. 2002. Hayek's Sensory Order. Theory \& Psychology. 2002, Vol. 12(3), pp. $125-147$.

ŠPECIÁN, P. 2012. Od Misese k Schutzovi. Otázka apriorismu v ekonomii. Politická ekonomie, sv. 60, č. 3, s. 395-410. 
THALER, R. H. 1980. Toward a Positive Theory of Consumer Choice. Journal of Economic Behavior and Organization. 1980, Vol. 1, pp. 39-60. 


\section{E-LOGOS}

ELECTRONIC JOURNAL FOR PHILOSOPHY

Ročník/Year: 2013 (vychází průběžně/ published continuously)

Místo vydání/Place of edition: Praha

ISSN 1211-0442

Vydává/Publisher:

Vysoká škola ekonomická v Praze / University of Economics, Prague

nám. W. Churchilla 4

Czech Republic

13067 Praha 3

IČ: 61384399

Web: http://e-logos.vse.cz

Redakce a technické informace/Editorial staff and technical information:

Miroslav Vacura

vacuram@vse.cz

Redakční rada/Board of editors:

Ladislav Benyovszky (FHS UK Praha, Czech Republic)

Ivan Blecha (FF UP Olomouc, Czech Republic)

Martin Hemelík (VŠP Jihlava, Czech Republic)

Angelo Marocco (Pontifical Athenaeum Regina Apostolorum, Rome, Italy)

Jozef Kelemen (FPF SU Opava, Czech Republic)

Daniel Kroupa (ZU Plzeň, Czech Republic)

Vladimír Kvasnička (FITT STU Bratislava, Slovak Republic)

Jaroslav Novotný (FHS UK Praha, Czech Republic)

Jakub Novotný (VŠP Jihlava, Czech Republic)

Ján Pavlík (editor-in-chief) (VŠE Praha, Czech Republic)

Karel Pstružina (VŠE Praha, Czech Republic)

Miroslav Vacura (executive editor) (VŠE Praha, Czech Republic) 